\title{
Comparison of safe weed control methods with chemical herbicide in potato field
}

\author{
Ibrahim Mohamed El-Metwally and Mona Adel El-Wakeel ${ }^{*}$ (D)
}

\begin{abstract}
Background: Mulching and manual or mechanical hoeing are the backbone of weed control strategies in organic agriculture. So, two field experiments were established in the village of Kafer El-Khawazim, Talkha district, Dakahlia Governorate, Egypt, during the winter seasons of 2017 and 2018. The experiments were conducted to evaluate the efficiency of the safe weed control methods of mulching and manual hoeing in comparison with metribuzine herbicide on potato plants and associated weeds.

Results: The results indicated that the treatment of black plastic mulch was the superior treatment in controlling broadleaved, grassy, and total weeds as compared to other treatments under study. Metribuzin herbicide came in the second rank in controlling broadleaved weeds. Concerning to grassy and total weeds, banana leaf and cheeseweed straw mulches follow the black plastic mulch ideal treatment. The results also revealed that the use of black plastic mulch and banana leaf mulch followed by cheeseweed straw mulch led to the highest significant increase in growth characteristics and tuber yield of potato plants. This in turn correlated with a significant increase in tuber contents of phosphorus, potassium, and carbohydrate percentage than unweeded control treatment.

Conclusion: Black plastic mulch followed by banana leaf mulch and cheeseweed straw mulch were the ideal safe treatments in controlling total weeds. This in turn reflected on potato plants by scoring the maximum values of yield characters as compared to unweeded check.
\end{abstract}

Keywords: Hoeing, Metribuzin, Mulching, Potato weeds, Total carbohydrate and vitamin C

\section{Background}

Potato (Solanum tuberosum) is one of the most important commercial vegetable crops in Egypt for local market and export to some European countries. Weed competition had negative effects on potato crop expressed in reducing tuber yield by $32.7 \%$ (Bhullar et al. 2015) and up to $86 \%$ as well as tuber quality. Weed infestation removes nutrients from the soil which reflects negatively on crop yield (Shehata et al. 2017). Weeds not only compete with crop plants for nutrients, soil moisture, space, and light but also serve as an alternative hosts for numerous insect pests and diseases. So, control of weeds in the early stages appears imperative as it plays a vital role in maximizing the tuber production.

Manual weeding is a conventional practice and quite effective, but it is expensive, tedious, and time-consuming and also may cause root injury (Khurana et al. 1993).

\footnotetext{
* Correspondence: m.elwakeel2000@yahoo.com

Botany Department, Agriculture and Biological Division, National Research Centre, 33 El Bohouth St., Dokki, P.O. 12622, Giza, Egypt
}

However, timely weed control methods may not be possible manually due to disability of labors accompanied by their high rate of salary. Proper weed management strategy should be developed to reduce weed adverse impact on yield, thereby increasing the potato productivity.

Mulching reduces soil water evaporation, results to uniform soil moisture content, and reduces the amount of irrigating water, which is very important in doubling food production in Egyptian cultivated area with using available limited irrigating water supplies. Mulching avoids the fluctuations in temperature in the first $20-30-\mathrm{cm}$ depth in soils. Additionally, it promotes root development and the soil temperature in the planting bed gets raised, enhancing more rapidly crop development and earlier harvest (Lament 1993). Mulching with cereal straw, hay, or grass is used in the production of various crops such as potato. This by reducing virus infections, control weeds, increase crop yield, and most importantly conserve soil moisture (Saucke and Döring 2004). 
Mulching is a process of covering the soil before or after planting by natural or synthetic materials which continue throughout the crop growth period. Plant residues of rice straw, canola, lupine, sunflower, sugarcane, banana stem, waste of some vegetables like turnip, garlic, sawdust, and others can be used as natural mulching materials, whereas synthetic mulch such as plastic, geotextile materials, or magazine paper. Application of mulch increased the beets and cabbage yields by 135 and 124\%, respectively (Lekasi et al. 2001).

Organic mulch produced weed density and dry weight significantly less than the un-weeded control; it also produced $59.6 \%$ of weed control efficiency and $22.4 \%$ of weed index (Yadav et al. 2015). Rice straw mulch ( $7 \mathrm{t} / \mathrm{ha})$ increased potato tuber yield by $48.9 \%$ over the control (Bhullar et al. 2015). Organic mulch had significantly higher potato tuber yield than weedy check (Yadav et al. 2015). Hoeing scored the highest yield in most vegetable crops. Hoeing increased potato tuber yield by $6.34 \mathrm{t} / \mathrm{ha}$ (Bhullar et al. 2015).

Keeping in this view, two experiments were carried out to evaluate the comparative efficacy of chemical and nonchemical methods of weed management in potato and associated weeds.

\section{Materials and methods}

Two field experiments were carried out at Kafer El-Khawazim, Talkha district, Dakahlia Governorate, Egypt, during the winter seasons of 2017and 2018 to examine the effect of different straw mulches, black poly ethylene mulch, and metribuzin herbicide on weed, vegetative growth, yield of potato crop, and some physical chemical characters of tubers. The experimental design was randomized complete block design with four replicates. The plot area was $10.5 \mathrm{~m}^{2}(1 / 400$ of fed., contained four rows $3.75 \mathrm{~m}$ length and $0.7 \mathrm{~m}$ width). The soil texture of the experimental site was clay loam with $1.23 \%$ organic matter, $0.15 \%$ total nitrogen, and $\mathrm{pH}$ of 7.5. Seeds (tubers) of potato crop Spunta cv. were planted at first week in January in both seasons. Cultural management and pest control programs were applied according to the recommendations of the Egyptian Ministry of Agriculture. Flooding irrigation was applied according to standard recommendations; the irrigation was stopped 1 week before harvesting.

The experiments included 10 treatments representing in six organic mulches (rice straw, wheat straw, cheeseweed straw, salix straw, guava leaf straw, banana leaf straw), black plastic mulch, hoeing twice at 21 and 49 days after sowing (DAS) and metribuzin herbicide (sencor $70 \% \mathrm{WP}$ ) at $700 \mathrm{~g} / \mathrm{ha}$ in addition to unweeded check (control treatment). Black plastic thickness was $60 \mu$, whereas $10 \mathrm{t} / \mathrm{ha}$ straw mulches were applied by hand in $4 \mathrm{~cm}$ thickness. All mulches were applied at 30
DAS and remained in the soil to the harvest. Metribuzin was applied before emergence of potato seedlings, using knapsack sprayer at $500 \mathrm{l}$ water solution/ha.

\section{Recorded data \\ Weeds}

Weed density was recorded at 70 DAS and at harvest (110 DAS), and then, weed samples were collected randomly from $1 \mathrm{~m}^{2}$. Weeds were classified into two groups, i.e., annual broadleaved and grassy then dry weight of weeds were recorded after drying in a forced draft oven at $70{ }^{\circ} \mathrm{C}$ for $72 \mathrm{~h}$.

\section{Potato crop}

Vegetative growth At 70 DAS, samples of five potato plants were taken from the central area of each plot for the determining plant height, number of leaves/plant, dry weight/plant, and leaf area/plant.

Yield traits At harvest (110 DAS), a sample of 10 tubers was taken to measure weight, diameter, length, and specific gravity of tubers. Total yield tuber yield ha ${ }^{-1}$ was determined by harvesting the whole plot area.

Tuber quality Total soluble solids (TSS \%) using a hand refractometer, total carbohydrates (Bogdan et al. 1993), and vitamin $\mathrm{C}$ content (AOAC 1980) as well as $N, P$, and K\% (Rangana 1979) were estimated.

\section{Statistical analysis}

The data obtained were subjected to analysis of variance (ANOVA) according to Gomez and Gomez (1984), using CoStat Software Program Version 6.303 (2004), and LSD at 0.05 level of significance was used for the comparison between means.

\section{Results}

Firstly, the most abundant weed species in the present study were wild oat (Avena fatua L.) and ryegrass (Lolium temulentum L.) as annual grassy weeds; yellow sweetclover (Melilotus indicus L.), wild beet (Beta vulgaris L.), greater ammi (Ammi majus L.), dock (Rumex dentatus L.), and bur clover (Medicago hispida L.) as annual broad-leaved weeds in winter seasons of 2017 and 2018.

\section{Weed growth}

Results presented in Tables 1 and 2 as well as Fig. 1 revealed that the dry weight of broadleaved, grassy, and total weeds were significantly reduced by weed management practices, when compared to the unweeded treatment at 70 DAS and at harvest. In this regard, black plastic mulch achieved the highest weed depression expressed in the lowest dry matter of the mentioned 
Table 1 Effect of different weed control treatments on dry weight of associated potato weeds $\left(\mathrm{g} / \mathrm{m}^{2}\right)$ after 70 days from planting and at harvest during 2017 season

\begin{tabular}{|c|c|c|c|c|c|c|}
\hline \multirow[t]{3}{*}{ Treatments } & \multicolumn{6}{|c|}{2017 season } \\
\hline & \multicolumn{3}{|l|}{ At 70 days } & \multicolumn{3}{|l|}{ At harvest } \\
\hline & Broadleaved & Grassy & Total & Broadleaved & Grassy & Total \\
\hline Rice straw mulch & 8.75 & 9.92 & 18.67 & 25.12 & 21.12 & 46.24 \\
\hline Wheat straw mulch & 3.21 & 4.20 & 7.41 & 14.75 & 17.10 & 31.85 \\
\hline Cheeseweed straw mulch & 3.00 & 3.95 & 6.95 & 13.15 & 16.13 & 29.28 \\
\hline Salix straw mulch & 4.65 & 4.95 & 9.60 & 17.20 & 18.40 & 35.60 \\
\hline Guava leaf straw mulch & 5.42 & 6.12 & 11.54 & 19.70 & 19.10 & 38.80 \\
\hline Banana leaf straw mulch & 2.23 & 3.74 & 5.97 & 12.71 & 15.72 & 28.43 \\
\hline Black plastic mulch & 1.52 & 2.17 & 3.69 & 7.13 & 8.22 & 15.35 \\
\hline Metribuzin & 2.12 & 6.15 & 8.27 & 10.14 & 22.60 & 32.74 \\
\hline Hoeing (twice) & 7.14 & 8.28 & 16.42 & 24.10 & 20.84 & 44.94 \\
\hline Unweeded check & 60.17 & 57.12 & 117.29 & 129.72 & 115.82 & 245.54 \\
\hline LSD 0.05 & 4.15 & 5.11 & 7.21 & 2.34 & 2.23 & 4.53 \\
\hline
\end{tabular}

weed groups. Reduction percentage in dry matter recorded relative to weed check treatment amounted to 97.47, 96.20, and $96.85 \%$ at 70 DAS and 94.50, 92.90, and $93.75 \%$ at harvest in the first season and amounted to $95.86,94.19$, and $95.11 \%$ at 70 DAS and 94.11, 93.03, and $93.59 \%$ at harvest in the second season in broadleaved, grassy, and total weeds, respectively. Metribuzin herbicide came in the second rank after black plastic mulch controlling in broadleaved, while banana leaf straw mulching came in the second rank after black plastic mulch followed by that of cheeseweed straw mulch controlling in grassy and total weeds. In contrast, the maximum values of dry weight of broadleaved, grassy, and total weeds were obtained by untreated treatment.

\section{Potato crop}

\section{Vegetative growth}

Weed management practices had a significant effect on potato growth (Table 3). All mulches, chemical, and mechanical treatments significantly increased plant height, number of leaves/plant, dry weight/plant, and leaf area/plant at 70 DAS in both seasons. Black plastic mulch and banana leaf straw mulch gave the maximum values of potato growth without significant between them. Cheeseweed straw mulch came in the second rank followed by that of wheat straw mulch as compared to unweeded check.

\section{Yield traits}

Weed management practices caused significant increases in average of tuber weight, tuber fresh weight/plant,

Table 2 Effect of different weed control treatments on dry weight of associated potato weeds $\left(\mathrm{g} / \mathrm{m}^{2}\right)$ after 70 days from planting and at harvest during 2018 season

\begin{tabular}{|c|c|c|c|c|c|c|}
\hline \multirow[t]{3}{*}{ Treatments } & \multicolumn{6}{|c|}{2018 season } \\
\hline & \multicolumn{3}{|l|}{ At 70 days } & \multicolumn{3}{|l|}{ At harvest } \\
\hline & Broadleaved & Grassy & Total & Broadleaved & Grassy & Total \\
\hline Rice straw mulch & 8.12 & 8.50 & 16.62 & 23.75 & 21.17 & 44.92 \\
\hline Wheat straw mulch & 5.98 & 4.13 & 10.11 & 19.32 & 18.21 & 36.57 \\
\hline Cheeseweed straw mulch & 5.61 & 4.00 & 9.61 & 17.12 & 17.25 & 35.33 \\
\hline Salix straw mulch & 7.13 & 4.45 & 11.58 & 22.11 & 19.23 & 41.34 \\
\hline Guava leaf straw mulch & 7.56 & 5.12 & 12.68 & 23.00 & 20.15 & 43.15 \\
\hline Banana leaf straw mulch & 4.71 & 3.75 & 8.46 & 15.65 & 16.17 & 31.82 \\
\hline Black plastic mulch & 3.11 & 3.61 & 6.72 & 9.25 & 10.11 & 19.36 \\
\hline Metribuzin & 3.18 & 6.15 & 9.93 & 12.11 & 25.17 & 37.28 \\
\hline Hoeing (twice) & 7.95 & 7.25 & 15.20 & 19.10 & 18.20 & 37.30 \\
\hline Unweeded check & 75.15 & 62.15 & 137.30 & 157.13 & 145.00 & 302.13 \\
\hline LSD 0.05 & 3.98 & 4.45 & 6.75 & 4.23 & 3.88 & 5.63 \\
\hline
\end{tabular}






$\mathbf{a}$

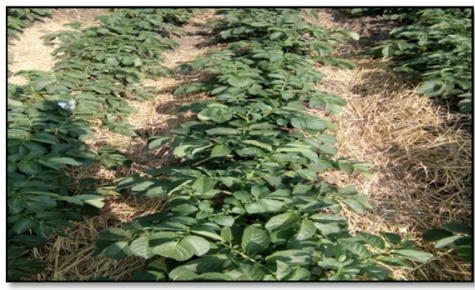

c

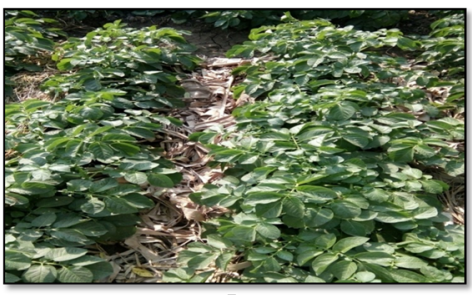

b

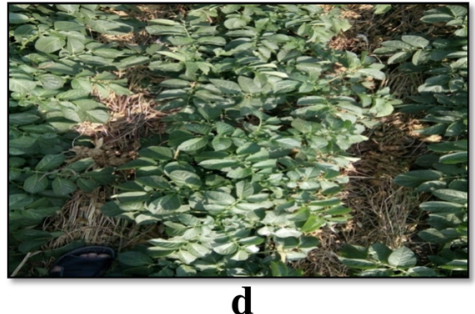

d

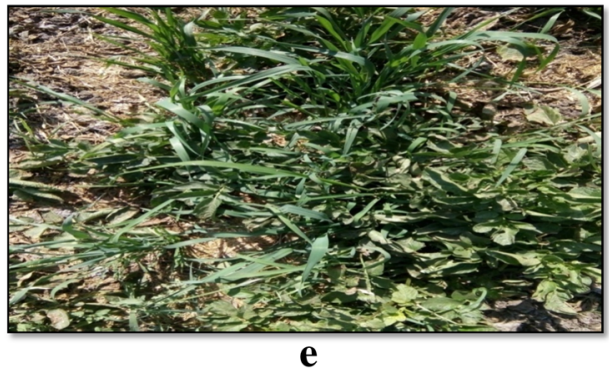

Fig. 1 a Black plastic mulch. b Banana straw mulch. c Rice straw mulch. d Cheeseweed straw mulch. e Unweeded treatments

tuber diameter, tuber length, and total yield (Tables 4 and 5). Black plastic mulch, banana leaf straw mulching, cheeseweed straw mulch, and wheat straw mulching treatments provided the maximum values in tuber fresh weight/plant, tuber diameter, tuber length, and total yield as compared to the unweeded treatment. The increases in tuber yield resulting from black plastic mulch, banana leaf straw mulching, cheeseweed straw mulching, and wheat straw mulching amounted to 77.90, 77.32, 75.26 , and $72.78 \%$ in the first season, and $79.80,77.46$, 75.86 , and $74.80 \%$ in the second season, respectively. In addition, salix straw mulch in the first season hoeing twice in the second one were the best treatments being enhanced tuber yield by 67.84 and $74.39 \%$, respectively, than the

Table 3 Effect of different weed control treatments on vegetative growth traits of potato plants after 70 days from planting during 2017 and 2018 seasons

\begin{tabular}{|c|c|c|c|c|c|c|c|c|}
\hline \multirow[t]{2}{*}{ Treatments } & \multicolumn{4}{|l|}{2017 season } & \multicolumn{4}{|l|}{2018 season } \\
\hline & $\begin{array}{l}\text { Plant height } \\
(\mathrm{cm})\end{array}$ & $\begin{array}{l}\text { Number of } \\
\text { leaves/plant }\end{array}$ & $\begin{array}{l}\text { Dry weight/ } \\
\text { plant (g) }\end{array}$ & $\begin{array}{l}\text { Leaf area/ } \\
\text { plant }\left(\mathrm{cm}^{2}\right)\end{array}$ & $\begin{array}{l}\text { Plant height } \\
(\mathrm{cm})\end{array}$ & $\begin{array}{l}\text { Number of } \\
\text { leaves/plant }\end{array}$ & $\begin{array}{l}\text { Dry weight/ } \\
\text { plant (g) }\end{array}$ & $\begin{array}{l}\text { Leaf area/ } \\
\text { plant }\left(\mathrm{cm}^{2}\right)\end{array}$ \\
\hline Rice straw mulch & 46.33 & 23.42 & 21.82 & 4495.71 & 50.11 & 28.15 & 25.07 & 4630.11 \\
\hline Wheat straw mulch & 52.52 & 27.72 & 26.90 & 4715.30 & 54.45 & 30.13 & 29.21 & 4830.70 \\
\hline Cheeseweed straw mulch & 52.74 & 28.04 & 27.45 & 4780.12 & 55.93 & 30.75 & 30.00 & 4875.21 \\
\hline Salix straw mulch & 50.32 & 26.03 & 26.24 & 4611.20 & 50.40 & 27.73 & 26.65 & 4681.10 \\
\hline Guava leaf straw mulch & 50.11 & 25.42 & 24.53 & 4569.11 & 52.75 & 28.56 & 27.15 & 4765.40 \\
\hline Banana leaf straw mulch & 53.10 & 28.34 & 28.05 & 4814.00 & 56.04 & 31.07 & 30.71 & 4925.12 \\
\hline Black plastic mulch & 53.19 & 28.50 & 28.12 & 4820.42 & 56.16 & 31.11 & 30.90 & 4995.31 \\
\hline Metribuzin & 48.31 & 25.11 & 23.41 & 4539.21 & 50.02 & 27.11 & 25.23 & 4670.30 \\
\hline Hoeing (twice) & 47.42 & 23.92 & 22.60 & 4511.11 & 51.21 & 28.19 & 26.00 & 4750.50 \\
\hline Unweeded check & 43.24 & 19.26 & 18.32 & 3348.80 & 44.31 & 20.13 & 19.70 & 3799.30 \\
\hline LSD 0.05 & 0.52 & 1.26 & 1.13 & 23.21 & 0.61 & 1.15 & 1.24 & 25.94 \\
\hline
\end{tabular}


Table 4 Effect of different weed control treatments on yield traits of potato plants during 2017 season

\begin{tabular}{|c|c|c|c|c|c|c|}
\hline \multirow[t]{2}{*}{ Treatments } & \multicolumn{6}{|l|}{2017 season } \\
\hline & $\begin{array}{l}\text { Average of tuber } \\
\text { weight }(\mathrm{g})\end{array}$ & $\begin{array}{l}\text { Tuber fresh } \\
\text { weight/plant (g) }\end{array}$ & $\begin{array}{l}\text { Tuber diameter } \\
(\mathrm{cm})\end{array}$ & $\begin{array}{l}\text { Tuber length } \\
(\mathrm{cm})\end{array}$ & $\begin{array}{l}\text { Total yield } \\
\text { (ton/ha) }\end{array}$ & $\begin{array}{l}\text { Specific gravity } \\
\left(\mathrm{g} / \mathrm{cm}^{3}\right)\end{array}$ \\
\hline Rice straw mulch & 145.9 & 565.2 & 6.20 & 9.9 & 35.70 & 1.054 \\
\hline Wheat straw mulch & 181.7 & 681.7 & 7.92 & 12.8 & 41.90 & 1.101 \\
\hline Cheeseweed straw mulch & 189.4 & 693.2 & 8.12 & 13.1 & 42.50 & 1.064 \\
\hline Salix straw mulch & 165.3 & 655.2 & 7.15 & 11.7 & 40.70 & 1.080 \\
\hline Guava leaf straw mulch & 160.7 & 625.9 & 7.03 & 10.6 & 39.70 & 1.070 \\
\hline Banana leaf straw mulch & 205.3 & 711.3 & 8.33 & 13.2 & 43.00 & 1.110 \\
\hline Black plastic mulch & 207.0 & 713.3 & 8.42 & 13.6 & 43.14 & 1.113 \\
\hline Metribuzin & 153.5 & 595.9 & 6.85 & 10.1 & 39.35 & 1.065 \\
\hline Hoeing (twice) & 181.0 & 640.2 & 7.20 & 12.3 & 39.00 & 1.107 \\
\hline Unweeded check & 145.7 & 405.1 & 5.65 & 9.0 & 24.25 & 1.120 \\
\hline LSD 0.05 & 2.1 & 12.2 & 0.43 & 1.1 & 1.71 & NS \\
\hline
\end{tabular}

unweeded check. No detected differences among all weed control treatments in specific gravity character obtained in both seasons. Vice-versa, unweeded check gave the lowest values of yield and yield traits in both seasons.

\section{Tuber quality}

Remarkable effects on $P, K$, and total carbohydrate percentages of tubers due to weed management were recorded (Tables 6 and 7). All mulching treatments, metribuzin, and hoeing twice treatments significantly increased the concentration of the previous characters as compared with unweeded. The maximum values of $P, K$, and total carbohydrate percentages of tubers were obtained from banana leaf straw mulching treatment. Black plastic mulch came in the second rank. On the other hand, unweeded check gave the lowest values of $P, K$, and total carbohydrate percentages in both seasons. There were no significant differences among all weed control treatments in N, TSS, and vitamin C characters in both seasons.

\section{Discussion}

Our study focused on evaluating the weed suppression ability using safe methods in comparing with standard rate of metribuzin herbicide. Herein, well impacts of the different used mulches against potato weeds were possessed. In this respect, Bakht and Khan 2014 reported that weed density in black plastic mulches was similar to hand weeding. Also, black plastic mulch, banana leaf straw, cheeseweed straw mulch, and rice straw mulch prevent the seed germination and growth of weeds by blocking the light penetration (Chang et al. 2016). Yadav et al. 2015 reported that the maximum weed control efficiency was observed under weed-free treatment followed by application of metribuzin. Cerdeira et al. 2012 reported that cogon grass, rice straw, and some types of sawdust have been reported

Table 5 Effect of different weed control treatments on yield traits of potato plants during 2018 season

\begin{tabular}{|c|c|c|c|c|c|c|}
\hline \multirow[t]{2}{*}{ Treatments } & \multicolumn{6}{|l|}{2018 season } \\
\hline & $\begin{array}{l}\text { Average of tuber } \\
\text { weight }(\mathrm{g})\end{array}$ & $\begin{array}{l}\text { Tuber fresh } \\
\text { weight/plant (g) }\end{array}$ & $\begin{array}{l}\text { Tuber diameter } \\
(\mathrm{cm})\end{array}$ & $\begin{array}{l}\text { Tuber length } \\
(\mathrm{cm})\end{array}$ & $\begin{array}{l}\text { Total yield } \\
\text { (ton/ha) }\end{array}$ & $\begin{array}{l}\text { Specific gravity } \\
\left(\mathrm{g} / \mathrm{cm}^{3}\right)\end{array}$ \\
\hline Rice straw mulch & 193.2 & 667.2 & 7.30 & 11.97 & 38.50 & 1.220 \\
\hline Wheat straw mulch & 194.1 & 681.7 & 740 & 12.32 & 42.65 & 1.032 \\
\hline Cheeseweed straw mulch & 197.4 & 689.3 & 7.65 & 12.65 & 42.91 & 1.059 \\
\hline Salix straw mulch & 185.2 & 655.3 & 7.00 & 11.80 & 36.68 & 1.018 \\
\hline Guava leaf straw mulch & 190.7 & 645.1 & 7.07 & 11.75 & 36.45 & 1.007 \\
\hline Banana leaf straw mulch & 211.7 & 719.8 & 8.45 & 13.42 & 43.30 & 1.115 \\
\hline Black plastic mulch & 218.3 & 725.7 & 8.49 & 13.51 & 43.87 & 1.118 \\
\hline Metribuzin & 195.3 & 685.7 & 7.82 & 12.87 & 41.25 & 1.075 \\
\hline Hoeing (twice) & 201.2 & 709.2 & 7.07 & 12.09 & 42.55 & 1.102 \\
\hline Unweeded check & 151.3 & 475.2 & 5.40 & 8.75 & 24.40 & 1.118 \\
\hline LSD 0.05 & 3.1 & 15.2 & 0.39 & 0.95 & 1.63 & NS \\
\hline
\end{tabular}


Table 6 Effect of different weed control treatments on tuber quality of potato during 2017 season

\begin{tabular}{lllllll}
\hline Treatments & \multicolumn{2}{l}{ 2017 season } & & & & \\
\cline { 2 - 7 } & TSS\% & N\% & P\% & K\% & Total carbohydrate \% & Vitamin C mg/g \\
\hline Rice straw mulch & 5.63 & 1.45 & 0.534 & 0.85 & 75.32 & 11.39 \\
Wheat straw mulch & 5.75 & 1.53 & 0.682 & 0.87 & 79.40 & 11.45 \\
Cheeseweed straw mulch & 5.35 & 1.60 & 0.559 & 0.79 & 76.23 & 11.34 \\
Salix straw mulch & 5.72 & 1.72 & 0.732 & 0.90 & 81.45 & 11.65 \\
Guava leaf straw mulch & 5.47 & 1.60 & 0.706 & 0.80 & 78.91 & 11.19 \\
Banana leaf straw mulch & 5.75 & 1.75 & 0.755 & 0.95 & 82.73 & 11.79 \\
Black plastic mulch & 5.55 & 1.59 & 0.736 & 0.93 & 82.00 & 11.71 \\
Metribuzin & 5.61 & 1.39 & 0.606 & 0.75 & 72.71 & 11.03 \\
Hoeing (twice) & 5.49 & 1.64 & 0.595 & 0.82 & 80.72 & 11.10 \\
Unweeded check & 5.34 & 1.26 & 0.478 & 0.70 & 70.11 & 10.90 \\
LSD 0.05 & NS & NS & 0.063 & 0.04 & 1.32 & NS \\
\hline
\end{tabular}

to be allelopathic potential in controlling weeds. Straw mulch and cogongrass was better than sawdust in controlling weeds because of the slow de-composition of rice straw caused a high C:N ratio (Awodoyin et al. 2007). These results are in general agreement with those recorded by Ahmed and El-Metwally 2001, Abouziena et al. 2015, Bhullar et al. 2015 and Shehata et al. 2017.

Application of the weed control treatments was effective in controlling weeds (Tables 1 and 2) and consequently light, water, and nutrients were available to promote potato growth as compared to unweeded treatment. Also, mulching caused rising the temperature of the soil, which would lead to promote root development since warming soil may rise and promote more rapidly crop development and earlier harvest (Lament 1993). These results are in agreement with those recorded by Sajid et al. 2013 and Shehata et al. 2017.

The superiority of weeded treatments attributed with minimizing weed-crop competition (Tables 1 and 2), enhancing potato growth (Table 3) and high yield of potato, is realized (Tables 4 and 5). Moreover, as the competition for environmental factors decreased, the uptake of different nutrients increased and reflected on chemical composition of tubers (Tables 6 and 7). Coolong 2012 reported that straw mulching improved soil health by improving soil structure, increased organic matter in the soil, improved mineral nutrition, and enhanced soil bioactivity and yields. Soil moisture in mulched plots is not only higher, but is more stable during the entire growing season (Sinkevičienè et al. 2009). Studies on organic mulch in crops indicate that sawdust, bur-clover weed, rice straw, or cogon grass can reduce weed populations in organic farming system by inhibiting weed emergence and subsequent growth (Abouziena et al. 2008; Sinkevičiene et al. 2009; and Coolong 2012). The positive effect of weed management practices on potato yield has been confirmed by Dvoř́k et al. 2012, Shehata et al. 2017, and Zhang et al. 2017. There is a direct relationship between the applied

Table 7 Effect of different weed control treatments on tuber quality of potato during 2018 season

\begin{tabular}{lllllll}
\hline Treatments & \multicolumn{2}{l}{ 2018 season } & & & & \\
\cline { 2 - 6 } & TSS\% & N\% & P\% & K\% & Total carbohydrate \% & Vitamin C mg/g \\
\hline Rice straw mulch & 5.67 & 1.50 & 0.661 & 0.823 & 77.75 & 10.85 \\
Wheat straw mulch & 5.77 & 1.61 & 0.652 & 0.811 & 77.30 & 10.92 \\
Cheeseweed straw mulch & 5.55 & 1.59 & 0.675 & 0.875 & 78.14 & 10.75 \\
Salix straw mulch & 5.71 & 1.79 & 0.731 & 0.911 & 80.75 & 11.11 \\
Guava leaf straw mulch & 5.52 & 1.62 & 0.645 & 0.791 & 75.11 & 10.59 \\
Banana leaf straw mulch & 5.82 & 1.84 & 0.762 & 0.971 & 82.92 & 11.55 \\
Black plastic mulch & 5.59 & 1.67 & 0.752 & 0.930 & 82.11 & 11.29 \\
Metribuzin & 5.60 & 1.52 & 0.711 & 0.855 & 80.51 & 11.00 \\
Hoeing (twice) & 5.63 & 1.72 & 0.751 & 0.952 & 81.85 & 11.42 \\
Unweeded check & 5.39 & 1.21 & 0.481 & 0.711 & 71.35 & 10.65 \\
LSD 0.05 & NS & NS & 0.071 & 0.052 & 1.45 & NS \\
\hline
\end{tabular}


weed management practices and the increasing in tuber quality. These results are in accordance with those recorded by Ahmed and El-Metwally 2001 and El-Metwally et al. 2010.

\section{Conclusion}

It could be concluded that farmers can certainly depend on mulching instead of using chemical herbicides especially in organic farm systems for controlling potato weeds. Black plastic mulch, banana leaf mulch, and cheeseweed straw mulch were the most effective mulches in potato field. These safe and costless methods exhibited excellent control of weeds and scored the best growth characteristics as well as tuber yield and quality of potato plants.

\section{Abbreviations}

DAS: Days after sowing; TSS: Total soluble solids

\section{Acknowledgements}

This work was supported and funded by National Research Centre through the project entitled: (Some strategies for improving weed control efficacy in some export crops). Project No. (11040202), during in-house projects strategy 2016-2019.

\section{Funding}

This work was supported and funded by National Research Centre through the project titled: (Some strategies for improving weed control efficacy in some export crops). Project No. (11040202), during in-house projects strategy 2016-2019.

\section{Availability of data and materials}

The datasets generated and/or analysed during the current study are included in this published.

\section{Authors' contributions}

IEM and MEW preformed the field experiments. IEM wrote the paper, and MEW performed the chemical analysis of the samples and coordinated the data collection and analysis. Both authors read and approved the final manuscript.

\section{Authors' information}

Prof. Dr. Ibrahim Mohamed El-Metwally prof. at National Research Centre, Dokki, Giza, Botany Department; Agicultural and Biological Division. Dr. Mona Adel El-Wakeel researcher at National Research Centre, Dokki, Giza, Botany Department; Agicultural and Biological Division.

\section{Ethics approval and consent to participate}

Not applicable

\section{Consent for publication}

Not applicable

\section{Competing interests}

The authors declare that they have no competing interests.

\section{Publisher's Note}

Springer Nature remains neutral with regard to jurisdictional claims in published maps and institutional affiliations.

Received: 21 October 2018 Accepted: 16 January 2019

Published online: 30 January 2019

\section{References}

Abouziena HF, Hafez OM, El-Metwally IM, Sharma SD, Singh M (2008) Comparison of weed suppression and mandarin fruit yield and quality obtained with organic mulches, synthetic mulches, cultivation and glyphosate. Hort Sci 43:795-799
Abouziena HF, Radwan SM, El-Dabaa MAT (2015) Comparison of potato yield quality and weed control obtained with different plastic mulch colures. Middle East J Applied Sci 5(2):374-382

Ahmed SA, El-Metwally IM (2001) Comparative effect of some weed control treatments on potato (Solanum tuberosum, L.). J Agric Sci Mansoura Univ 26(4):2083-2098

AOAC (1980) Official methods of analysis, 13th edn. Association of Official Analytical. Chemists, Washington DC, pp 376-384

Awodoyin RO, Ogbeide Fl, Oluwole O (2007) Effects of three mulch types on the growth and yield of tomato (Lycopersicon esculentum Mill.) and weed suppression in Ibadan, rainforest-savanna transition zone of Nigeria. Trop Agri Res Exten 10:53-61

Bakht T, Khan IA (2014) Weed control in tomato (Lycopersicon Esculentum Mill.) through mulching and herbicides. Pak J Bot 46(1):289-292

Bhullar MS, Kaur S, Kaur T, Jhala AJ (2015) Integrated weed management in potato using straw mulch and atrazine. Hort Tech 25(3):335-339

Bogdan AS, Guenter W, Campbell LD (1993) New approach to water-soluble carbohydrate determination as a tool for evaluation of plant cell walldegrading enzymes. J Agric Food Chem 41(12):2304-2308

Cerdeira AL, Cantrell CL, Dayan FE, Byrd JD, Duke SO (2012) Tabanone, a new phytotoxic constituent of cogongrass (Imperata cylindrica). Weed Sci 60:212-218

Chang DC, Cho JH, Jin YI, Im JS, Cheon CG, Kim SJ, Yu HS (2016) Mulch and planting depth influence potato canopy development underground morphology and tuber yield. Field Crops Res 197:117-124

Coolong T (2012) Mulches for weed management. In: Price A (ed) Weed control. InTech, Shanghai, pp 57-74 (http://cdn.intechopen.com/pdfs/29919/InTechMulches_for_weed_management_mulches_for_weed_management.pdf in vegetable-production)

Dvořák P, Tomášek J, Kuchtová P, Hamouz K, Hajšlová J, Schulzová V (2012) Effect of mulching materials on potato production in different soil climatic condition. Romanian Agric Res 29:201-209

El-Metwally IM, El-Rokiek KGA, Ahmed SA, El-Desoki ER, Abd-Elsalam EEH (2010) Effect of adding urea or ammonium sulphate on some herbicides efficiency in controlling weeds in onion plants. J of American Sci 6(11): 536-543

Gomez KA, Gomez AA. Statistical procedures for agriculture research. A Wiley Inter Science Publication, Wiley, New York, 1984

Khurana SC, Thakral KK, Bhatia KK (1993) Effect of pendimethalin and isoproturon on weeds and tubers yield of potato. Indian Potato Assoc 20(3-4):255-257

Lament WJ (1993) Plastic mulches for the production of vegetable crops. Hort Technol 3(1):35-39

Lekasi JK, Woomer PL, Tenywa JS, Bekunda MA (2001) Effect of mulching cabbage with banana residues on cabbage yield, soil nutrient, soil biota and moisture and weed biomass. African Crop Sci J 9(3):499-506

Rangana S (1979) Manual of analysis of fruit and vegetables products. Tata McGrow Hill Publishing Company Limited, New Delhi, p 634

Sajid M, Hussain I, Khan IA, Rab A, Jan I, Wahid F, Shah S (2013) Influence of organic mulches on growth and yield components of pea's cultivars. Greener J Agric Sci 3(8):652-657

Saucke H, Döring TF (2004) Potato virus Y reduction by straw mulch in organic potatoes. Ann Appl Biol 144:347-355

Shehata SA, Abozien HF, Abd El-Gawad KF, Elkhawaga FA (2017) Safe weed management methods as alternative to synthetic herbicides in potato. Res J Pharm, Biol Sci 8(2):1148-1156

Sinkevičienè A, Jodaugienè D, Pupalienè R, Urbonienè M (2009) The influence of organic mulches on soil properties and crop yield. Agron Res 7(Special issue l):485-491

Yadav SK, Lal SS, Srivastava AK, Bag TK, Singh BP (2015) Efficacy of chemical and non-chemical methods of weed management in rainfed potato (Solanum tuberosum). Indian J Agric Sci 85(3):382-386

Zhang L, Wang FX, Shock CC, Yang KJ, Kang SZ, Qin JT, Li SE (2017) Influence of different plastic film mulches and wetted soil percentages on potato grown under drip irrigation. Agric Water Manag 180:160-171 